\title{
Marine-Derived 2-Aminoimidazolone Alkaloids. Leucettamine B-Related Polyandrocarpamines Inhibit Mammalian and Protozoan DYRK \& CLK Kinases
}

\author{
Nadège Loaëc ${ }^{1,2}$, Eletta Attanasio ${ }^{1}$, Benoît Villiers ${ }^{1}$, Emilie Durieu ${ }^{1}$, Tania Tahtouh ${ }^{1}$, \\ Morgane Cam ${ }^{1}$, Rohan A. Davis ${ }^{3}$ (i) , Aline Alencar ${ }^{4}$, Mélanie Roué ${ }^{5}$, \\ Marie-Lise Bourguet-Kondracki ${ }^{5}$, Peter Proksch ${ }^{6}$, Emmanuelle Limanton ${ }^{7}$, Solène Guiheneuf ${ }^{7}$, \\ François Carreaux ${ }^{7, *}$, Jean-Pierre Bazureau ${ }^{7, *}$, Michelle Klautau ${ }^{4, *}$ and Laurent Meijer ${ }^{1, *}$ \\ 1 ManRos Therapeutics, Perharidy Research Center, 29680 Roscoff, Bretagne, France; \\ nadege.loaec@univ-brest.fr (N.L.); attanasio@manros-therapeutics.com (E.A.); bvilliers@yahoo.fr (B.V.); \\ durieu@manros-therapeutics.com (E.D.); tania.tahtouh@gmail.com (T.T.); cam.morgane@live.fr (M.C.) \\ 2 Station Biologique de Roscoff, CNRS, ‘Protein Phosphorylation and Human Disease' Group, Place G. \\ Teissier, 29680 Roscoff, Bretagne, France \\ 3 Griffith Institute for Drug Discovery, Griffith University, Brisbane, QLD 4111, Australia; \\ r.davis@griffith.edu.au \\ 4 Universidade Federal do Rio de Janeiro, Instituto de Biologia—Departamento de Zoologia, Av. Carlos \\ Chagas Filho 373-CCS-Bloco A-Sala A0-100, Ilha do Fundão, 21941-902 Rio de Janeiro, Brazil; \\ aalencar@biologia.ufrj.br \\ 5 Molécules de Communication et Adaptation des Micro-Organismes, UMR 7245 CNRS, Muséum National d' \\ Histoire Naturelle, 57 rue Cuvier (C.P. 54), 75005 Paris, France; mroue@mnhn.fr (M.R.); \\ bourguet@mnhn.fr (M.-L.B.-K.) \\ 6 Institut für Pharmazeutische Biologie und Biotechnologie, Universitätsstr. 1, 40225 Düsseldorf, Germany; \\ proksch@duesseldorf-uni.de \\ 7 Université de Rennes 1, Institut des Sciences Chimiques de Rennes, ISCR UMR CNRS 6226, Groupe Chimie \\ Organique et Interfaces (CORINT), Bât. 10A, Campus de Beaulieu, Avenue du Général Leclerc, CS 74205, \\ 35042 Rennes CEDEX, Bretagne, France; emmanuelle.limanton@univ-rennes1.fr (E.L.); \\ solene.guiheneuf@univ-rennes1.fr (S.G.) \\ * Correspondence: francois.carreaux@univ-rennes1.fr (F.C.); jean-pierre.bazureau@univ-rennes1.fr (J.-P.B.); \\ mklautau@biologia.ufrj.br (M.K.); meijer@manros-therapeutics.com (L.M.); Tel.: +33-223-235-734 (F.C.); \\ +33-223-236-603 (J.-P.B.); +55-21-3938-6551 (M.K.); +33-608-605-834 (L.M.)
}

Received: 30 August 2017; Accepted: 12 October 2017; Published: 17 October 2017

\begin{abstract}
A large diversity of 2-aminoimidazolone alkaloids is produced by various marine invertebrates, especially by the marine Calcareous sponges Leucetta and Clathrina. The phylogeny of these sponges and the wide scope of 2-aminoimidazolone alkaloids they produce are reviewed in this article. The origin (invertebrate cells, associated microorganisms, or filtered plankton), physiological functions, and natural molecular targets of these alkaloids are largely unknown. Following the identification of leucettamine B as an inhibitor of selected protein kinases, we synthesized a family of analogues, collectively named leucettines, as potent inhibitors of DYRKs (dual-specificity, tyrosine phosphorylation regulated kinases) and CLKs (cdc2-like kinases) and potential pharmacological leads for the treatment of several diseases, including Alzheimer's disease and Down syndrome. We assembled a small library of marine sponge- and ascidian-derived 2-aminoimidazolone alkaloids, along with several synthetic analogues, and tested them on a panel of mammalian and protozoan kinases. Polyandrocarpamines A and B were found to be potent and selective inhibitors of DYRKs and CLKs. They inhibited cyclin D1 phosphorylation on a DYRK1A phosphosite in cultured cells. 2-Aminoimidazolones thus represent a promising chemical scaffold for the design of potential therapeutic drug candidates acting as specific inhibitors of disease-relevant kinases, and possibly other disease-relevant targets.
\end{abstract}


Keywords: marine sponge; Porifera; Calcarea; ascidian; Polyandrocarpa; 2-aminoimidazolone alkaloids; leucettamine B; leucettine; polyandrocarpamines; protein kinases; DYRK; CLK; kinase inhibitor; Alzheimer's disease; Down syndrome

\section{Introduction}

Protein kinases catalyze the phosphorylation of proteins on serine, threonine and tyrosine residues [1]. They represent a large family of intracellular regulators which, after their initial discovery by Edwin Krebs and Edmund Fisher in the 1950s [2], has seen massive research investment on their functions and regulations. The human kinome comprises 518 kinases, many of which display some abnormal activity or deregulation in human disease. This prompted both academic and pharmaceutical laboratories to search for, optimize, characterize and develop pharmacological inhibitors of selected disease-relevant protein kinases. As a matter of fact, kinases have become the leading therapeutic target in the pharmaceutical industry, before G-protein coupled receptors, and over 30 inhibitors have already reached the clinical market $[1,3,4]$. Although many inhibitors were initially derived from natural products, all drug candidates are chemically synthesized at some stage of their development towards a therapeutic drug.

During a general screen for inhibitors of cell signaling and cell cycle control kinases, we identified the marine sponge product leucettamine $B$ as a weak inhibitor of various protein kinases $[5,6]$. Following this initial discovery, a large number of analogues and derivatives were synthesized and optimized as kinase inhibitors, especially as inhibitors of the DYRKs (dual-specificity, tyrosine regulated kinases) and CLKs (cdc2-like kinases) kinase families. Leucettamine B-derived inhibitors are collectively named leucettines [6,7]. These inhibitors have a potential as drug candidates for the treatment of cognitive disorders associated with Down syndrome (DS) and Alzheimer's disease (AD), but also for some cancers, inflammation, diabetes, and so forth.

Leucettamine B was initially identified in the marine, calcareous sponge Leucetta microraphis [8]. The physiological function of this marine alkaloid is unknown, as is the biosynthetic pathway leading its production. Furthermore, whether leucettamine B is produced by the sponge itself or by some associated microorganisms remains to be determined. Interestingly, leucettamine B shows a central 2-aminoimidazolone scaffold shared by several marine products produced by various marine sponges, most of which belonging to the class Calcarea, and by other marine invertebrates, such as ascidians and nudibranchs (Figure 1). Several extensive reviews on these marine alkaloids [9-11] and 2-aminoimidazolones in general [12] have been recently published. We thought it might be interesting to obtain some of these leucettamine B-related natural products to evaluate them as potential kinase inhibitors. This was also an opportunity to review the sponge species producing such molecules, with particular emphasis on Leucetta and Clathrina species, as well as the wide scope of 2-aminoimidazolones produced by marine organisms.

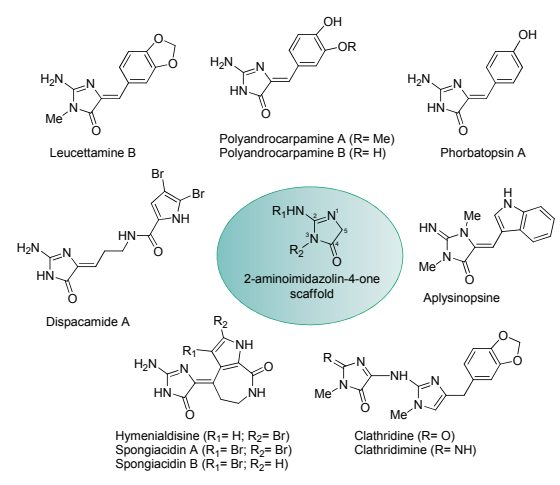

Figure 1. Structures of a selection of marine natural products sharing the 2-aminoimidazolin-4-one scaffold. 


\section{Results}

\subsection{Phylogeny of Calcareous Sponges with Special Emphasis on Leucetta and Clathrina}

Since most of the compounds described here are produced by marine calcareous sponges, we first present a phylogeny of these 2-aminoimidazolones-producing sponges, with specific focus on the Leucetta and Clathrina species. Sponges (phylum Porifera) are sessile, filter-feeding animals that utilize flagellate cells (choanocytes) to pump water through their bodies. They are morphologically very simple, as they do not have, for example, organs, sensorial cells or a nervous system. They are considered the oldest present metazoan (600 Ma) [13]. Four classes of extant sponges are currently accepted: Demospongiae, Hexactinellida, Homoscleromorpha, and Calcarea.

The class Calcarea Bowerbank, 1864, consists of a monophyletic group of marine sponges whose skeleton is formed by Mg-calcite spicules, while the others have spicules made of silica [14]. This class is composed of two subclasses, both monophyletic-Calcinea Bidder, 1898, and Calcaronea Bidder, 1898-which differ by cytological, embryological, ontogenetic and skeleton characteristics. In the Calcinea subclass, spicules are mainly regular (equiangular and equiradiate) and the first spicule to be synthesized during ontogeny is the triactine, while in Calcaronea, spicules are irregular and diactines are the first spicules to be produced. Moreover, the larvae in Calcinea is the calciblastula and the nucleus of the choanocytes is basal, while in Calcaronea the larvae is the amphiblastula and the nucleus of the choanocytes is apical. Calcareous sponges are considered viviparous and their larvae are lecytotrophic. Calcinea has two orders, Clathrinida Hartman, 1958, and Murrayonida Vacelet, 1981, the former being the most diverse. The genera Leucetta Haeckel, 1872, and Clathrina Gray, 1867, are part of the Clathrinida order (see Supplementary Data and Supplementary Figures S1-S4, and Supplementary Table S1 for detailed description and phylogeny of Leucetta and Clathrina species).

\subsection{Polyandrocarpamines Are Potent Inhibitors of the DYRK and CLK Kinases}

Leucettamine B [8] shares a 2-aminoimidazolone scaffold with various marine natural products such as polyandrocarpamines [15,16], dispacamide [17-19], aplysinopsine [20,21], clathridine/clathridimine [8,22], hymenialdisine/spongiacidin B [23-30] and phorbatopsin [31,32] (Figure 1). A summary of all marine aminoimidazolones described so far, and their natural sources and structures, is presented in Supplementary Table S2 and Supplementary Figure S5.

We tested a selection of these 2-aminoimidazolones (Figure 1) on a battery of 27 purified kinases (14 mammalian and 13 unicellular parasites (Supplementary Table S3)). Dose-response curves run with the active compounds provided $\mathrm{IC}_{50}$ values that are reported in Table 1 . As expected [29,30], hymenialdisine and the closely related spongiacidin B were very potent inhibitors of most kinases $\left(\mathrm{IC}_{50}\right.$ values in the 1-10 $\mathrm{nM}$ range). Yet they were not very selective, inhibiting essentially all tested kinases. With the exception of PfGSK-3, the Plasmodium falciparum orthologue of glycogen synthase kinase 3 (GSK-3) [33], and LmCK1, the Leishmania major orthologue of casein kinase 1 (CK1) [34], unicellular parasite kinases tended to be less sensitive than their mammalian counterparts.

Aplysinopsine, dispacamide, clathridine and clathridimine were essentially inactive in the kinase panel. As expected [6], leucettamine B was modestly active (sub-micromolar $\mathrm{IC}_{50}$ values), and leucettine L41 was potent on members of the DYRKs and CLKs families. Again, little inhibitory activity was detected with kinases from unicellular parasites. Finally, both polyandrocarpamines A and B were found to display significantly selective inhibitory effects on DYRKs and somewhat less on CLKs (Table 1). To investigate the selectivity of polyandrocarpamines, polyandrocarpamine A was screened on the large-scale DiscoveRx KinomeScan panel (Figure 2, Supplementary Table S4). This interaction assay provides a semi-quantitative scoring view of the affinity of a compound for any of 442 human kinases [35]. This comprehensive screening approach confirmed the rather good selectivity of polyandrocarpamine A for DYRKs, and detected additional affinity for CSNK2A1/A2, CLK1/4 (Table 2). 


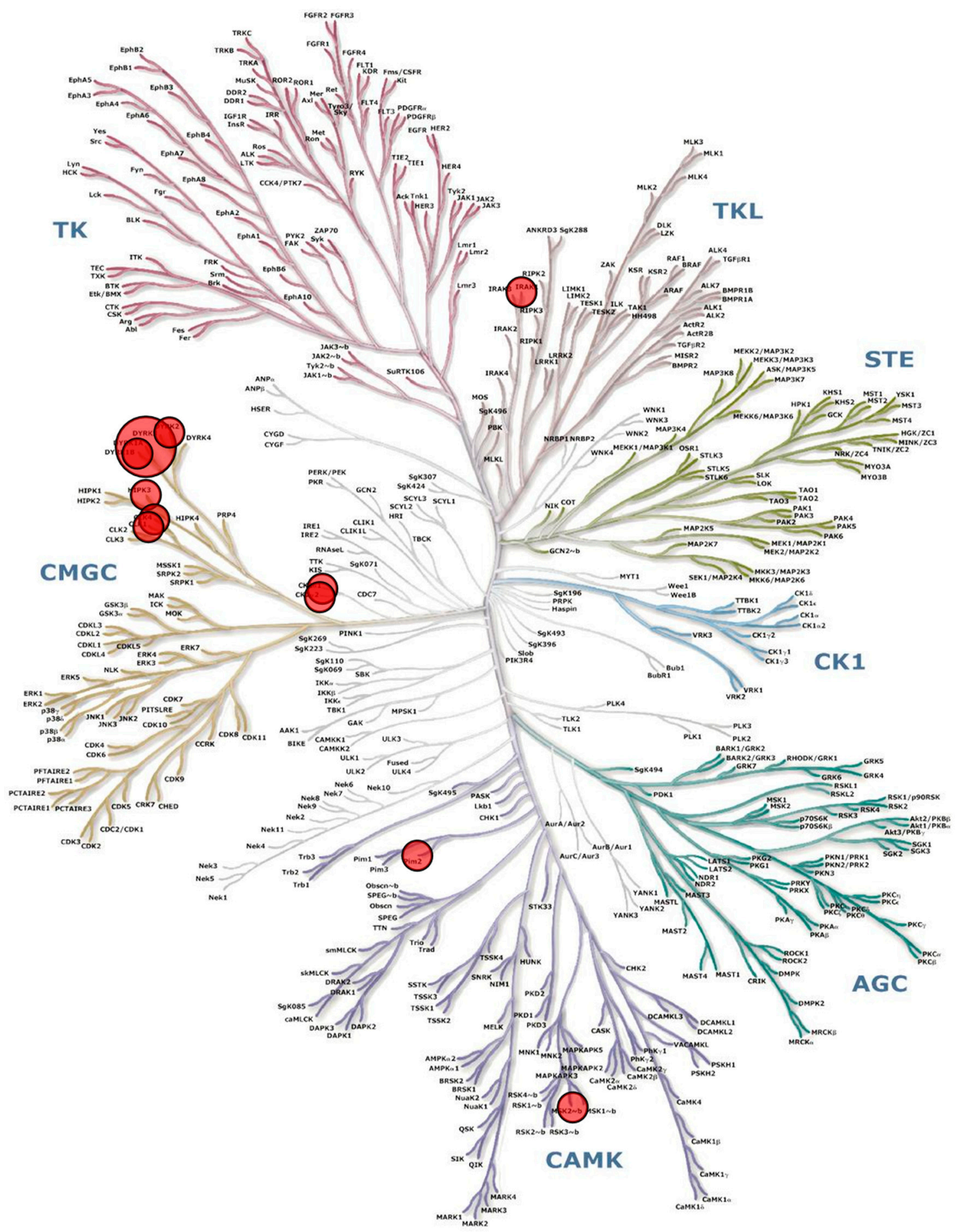

Figure 2. TREEspot ${ }^{\mathrm{TM}}$ kinase interaction map of polyandrocarpamine A with 442 human kinases (DiscoveRx KinomeScan ${ }^{\circledR}$, San Diego, CA, USA). Polyandrocarpamine A was tested at a $1 \mu \mathrm{M}$ final concentration in the kinase interaction panel. A semi-quantitative scoring of this primary screen was estimated. This score relates to a probability of a hit rather than strict affinity. Scores $>10$, between $1-10$ and $<1$ indicate that the probability of being a false positive is $<20 \%,<10 \%,<5 \%$, respectively. Results are presented in Table 2 and here as a TREEspot ${ }^{\mathrm{TM}}$ kinase interaction maps. Circles indicate the major hits and their size is proportional to the scores. All 442 values are provided in the Supplementary Table S4. 
Table 1. Protein kinase selectivity of a selection of 10 marine natural products sharing the 2-aminoimidazolone scaffold: leucettamine B and its synthetic leucettine L41 derivative; polyandrocarpamines A \& B, aplysinopsine, dispacamide, hymenialdisine, spongiacidin B, clathridine, and clathridimine. All compounds were tested at various concentrations against 27 purified kinases (14 mammalian and 13 unicellular parasites). IC $_{50}$ values (concentrations inducing $50 \%$ inhibition of maximal, non-inhibited kinase activity), calculated from the dose-response curves, are reported in $\mu \mathrm{M}$. IC 50 values below $1 \mu \mathrm{M}$ are shown in bold.

\begin{tabular}{|c|c|c|c|c|c|c|c|c|c|c|}
\hline Kinases & Leucettamine $B$ & Leucettine L41 & Polyandrocarpamine A & Polyandrocarpamine B & Aplysinopsine & Dispacamide & Hymenialdisine & Spongiacidin B & Clathridine & Clathridimine \\
\hline CDK1/cyclin B & $>10$ & $>10$ & $>10$ & $>10$ & $>10$ & $>10$ & 0.005 & 0.031 & $>10$ & $>10$ \\
\hline CDK2/cyclin A & $>10$ & $>10$ & $>10$ & $>10$ & $>10$ & $>10$ & 0.011 & 0.068 & $>10$ & $>10$ \\
\hline CDK5/p25 & $>10$ & $>10$ & $>10$ & $>10$ & $>10$ & $>10$ & 0.0061 & 0.042 & $>10$ & $>10$ \\
\hline CDK9/cyclin T & $>10$ & $>10$ & 0.93 & 5.2 & $>10$ & $>10$ & 0.011 & 0.2 & $>10$ & $>10$ \\
\hline 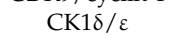 & $>10$ & 4.2 & 3.3 & $>10$ & $>10$ & $>10$ & 0.0037 & 0.031 & $>10$ & $>10$ \\
\hline CLK1 & 0.1 & 0.039 & 1.0 & 2.7 & $>10$ & $>10$ & 0.003 & 0.022 & 6.9 & 7.2 \\
\hline CLK2 & 0.91 & 0.21 & 1.2 & 4.9 & $>10$ & $>10$ & 0.0041 & 0.0073 & 6.0 & 6.1 \\
\hline CLK3 & 9.7 & 2.4 & 2.6 & 8.6 & $>10$ & $>10$ & 0.0053 & 0.049 & $>10$ & $>10$ \\
\hline CLK4 & 0.12 & 0.031 & 0.32 & 0.82 & $>10$ & $>10$ & 0.0029 & 0.0036 & 3.9 & 3.5 \\
\hline DYRK1A & 0.42 & 0.032 & 0.27 & 0.47 & $>10$ & $>10$ & 0.0033 & 0.78 & 7.8 & 5.2 \\
\hline DYRK1B & 1.8 & 0.05 & 0.43 & 1.2 & $>10$ & $>10$ & 0.0032 & 0.0058 & $>10$ & 5.6 \\
\hline DYRK2 & 0.49 & 0.088 & 0.42 & 0.76 & $>10$ & $>10$ & 0.0031 & 0.021 & 7.1 & 6.2 \\
\hline DYRK3 & 0.6 & 0.42 & 0.17 & 0.88 & $>10$ & $>10$ & 0.0049 & 0.044 & $>10$ & 6.1 \\
\hline GSK $-3 \alpha / \beta$ & 7.3 & 1.1 & $>10$ & $>10$ & $>10$ & $>10$ & 0.0032 & 0.044 & $>10$ & $>10$ \\
\hline PfGSK-3 & $>10$ & 8.5 & $>10$ & $>10$ & $>10$ & $>10$ & 0.0041 & 0.038 & $>10$ & $>10$ \\
\hline PfCLK1 & 0.79 & 0.42 & 0.65 & 3.1 & $>10$ & $>10$ & 0.011 & 0.085 & $>10$ & $>10$ \\
\hline LmCK1 & $>10$ & $>10$ & $>10$ & $>10$ & $>10$ & $>10$ & 0.0025 & 0.025 & $>10$ & $>10$ \\
\hline LmCLK & $>10$ & $>10$ & $>10$ & $>10$ & $>10$ & $>10$ & 0.4 & 5.2 & $>10$ & $>10$ \\
\hline LmDYRK2 & 4.2 & 2.9 & 5.9 & $>10$ & $>10$ & $>10$ & 0.38 & 9.0 & $>10$ & $>10$ \\
\hline LdDYRK1B & 6.9 & 0.82 & 1.1 & $>10$ & $>10$ & $>10$ & 0.042 & 0.5 & $>10$ & $>10$ \\
\hline LdDYRK3 & $>10$ & $>10$ & $>10$ & $>10$ & $>10$ & $>10$ & 0.021 & 0.3 & $>10$ & 7.9 \\
\hline LdDYRK4 & $>10$ & $>10$ & $>10$ & $>10$ & $>10$ & $>10$ & $>10$ & $>10$ & $>10$ & $>10$ \\
\hline TbCLK1 & $>10$ & $>10$ & $>10$ & $>10$ & $>10$ & $>10$ & 0.53 & 0.71 & $>10$ & $>10$ \\
\hline TcCLK1 & $>10$ & $>10$ & $>10$ & $>10$ & $>10$ & $>10$ & 0.51 & 1.1 & $>10$ & $>10$ \\
\hline CPLAMMER & 1.8 & 0.1 & 0.17 & 0.2 & $>10$ & $>10$ & 0.016 & 0.13 & $>10$ & $>10$ \\
\hline GlCLK & 3.1 & $>10$ & 0.95 & 2.2 & $>10$ & $>10$ & 0.012 & 0.12 & $>10$ & $>10$ \\
\hline TgCLK & 4.1 & $>10$ & $>10$ & $>10$ & $>10$ & $>10$ & 0.041 & 0.48 & $>10$ & $>10$ \\
\hline
\end{tabular}


Table 2. Protein kinase selectivity of polyandrocarpamine A in a kinase interaction assay (DiscoveRx KinomeScan ${ }^{\circledR}$ ). Polyandrocarpamine A was tested at $1 \mu \mathrm{M}$ on a 442 kinases interaction panel. A semi-quantitative scoring of this primary screen was obtained. This score relates to a probability of a hit rather than strict affinity. Scores $>10$, between $1-10$ and $<1$ indicate that the probability of being a false positive is $<20 \%,<10 \%,<5 \%$, respectively. The 11 best scores are presented. Full results are available in Supplementary Table S4.

\begin{tabular}{rcc}
\hline Kinases & Abbreviation & Score \\
\hline Dual specificity tyrosine-phosphorylation-regulated kinase 1A & DYRK1A & 3 \\
Casein kinase $2 \alpha$ & CSNK2A1 & 12 \\
Homeodomain interacting protein kinase 3 & HIPK3 & 19 \\
Proviral Integrations of Moloney virus 2 & PIM2 & 21 \\
Ribosomal protein S6 kinase alpha-4 (Kin.Dom.2-C-terminal) & RPS6KA4 & 22 \\
Dual specificity tyrosine-phosphorylation-regulated kinase 2 & DYRK2 & 24 \\
Dual specificity tyrosine-phosphorylation-regulated kinase 1B & DYRK1B & 25 \\
Casein kinase 2 $\alpha^{\prime}$ & CSNK2A2 & 26 \\
Interleukin-1 receptor-associated kinase 1 & IRAK1 & 28 \\
Cdc2-like kinase 4 & CLK4 & 30 \\
Cdc2-like kinase 1 & CLK1 & 32 \\
\hline
\end{tabular}

To confirm the effects of the active products on native DYRK1A in a cellular context, we made use of a SH-SY5Y neuroblastoma cell line expressing human DYRK1A [36] and antibodies directed against cyclin D1 phosphorylated at Threonine 286, a reported DYRK1A phosphorylation site [36,37] (Figure 3). SH-SY5Y-DYRK1A cells were exposed for $24 \mathrm{~h}$ to each product $(30 \mu \mathrm{M}$, except for hymenialdisine and leucettine L41, which were tested at $3 \mu \mathrm{M}$ ), cells were harvested and their proteins resolved by SDS-PAGE, followed by Western blotting with antibodies against P-Thr286-cyclin D1, total cyclin D1 and GAPDH (loading control) (Figure 3). Phosphorylation of cyclin D1 at Thr286 was partially inhibited by polyandrocarpamine A (better than polyandrocarpamine B, leucettine L41 and hymenialdisine, confirming the potent effects on DYRK1A in a cellular context.

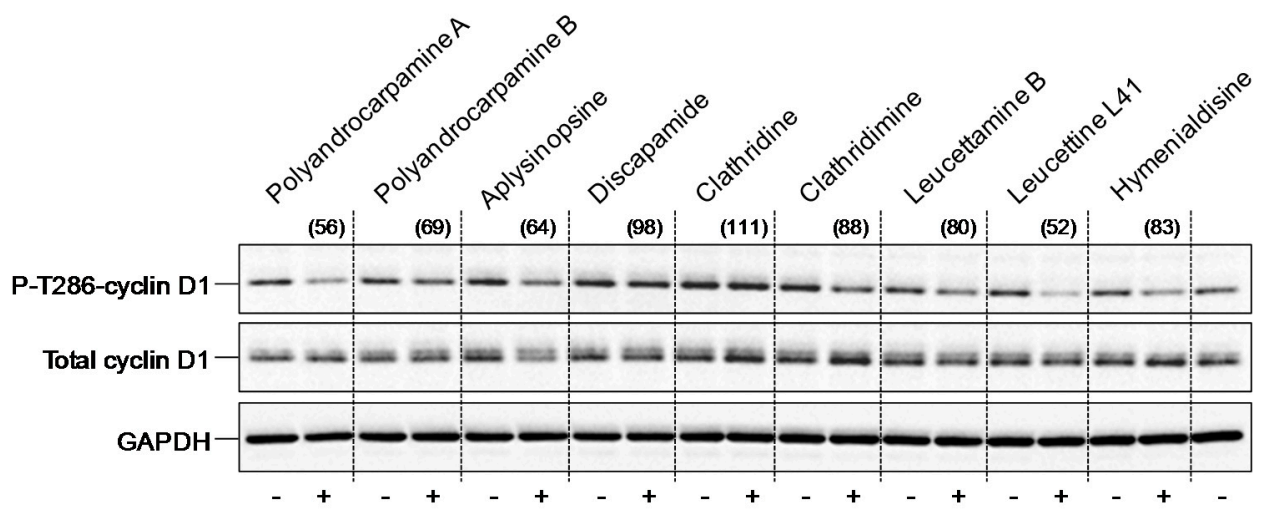

Figure 3. Inhibition of cyclin D1 Thr286 phosphorylation. SH-SY5Y cells expressing human DYRK1A were treated for $24 \mathrm{~h}$ with dimethylsulfoxide (DMSO) $(-)$ or $30 \mu \mathrm{M}$ of each compound (+) $(3 \mu \mathrm{M}$ for leucettine L41 and hymenialdisine). Proteins were resolved by SDS-PAGE and analyzed by Western blotting with antibodies directed against P-T286-cyclin D1, total cyclin D1 or glyceraldehyde-3-phosphate dehydrogenase (GAPDH) (used as loading control). Numbers in parentheses indicate the level of cyclin D1 phosphorylation relative to that of control, DMSO-treated cells $(100 \%)$.

To extend these results we synthesized both polyandrocarpamines, as well as a series of derivatives [38] (Figure 4), and tested them on a panel of 16 purified kinases. Synthesized (Table 3, PAC 1 and 2) and natural (Table 3, PAC 12 and 13) polyandrocarpamines showed very similar effects on the target kinases. In contrast, none of the synthetic analogues displayed significant efficacy in this kinase panel. 


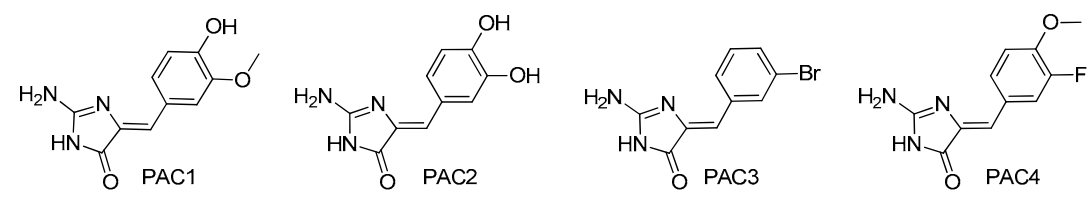<smiles></smiles><smiles></smiles><smiles>Cc1ccc(/C=C2\N=C(N)NC2=O)s1</smiles><smiles>Nc1nc(/C=C2\N=C(P)NC2=O)cs1</smiles>

Figure 4. Structure of synthetic analogues and derivatives of polyandrocarpamines (PAC1-PAC11) used in this study.

Table 3. Protein kinase selectivity of synthetic products derived from polyandrocarpamines A and B. All compounds were tested at various concentrations on 16 purified kinases (14 mammalian and two unicellular parasites). $\mathrm{IC}_{50}$ values, calculated from the dose-response curves, are reported in $\mu \mathrm{M}$. $\mathrm{IC}_{50}$ values below $1 \mu \mathrm{M}$ are shown in bold. PAC1 and PAC2, PAC12 and PAC13 are synthetic and natural polyandrocarpamines A and B, respectively.

\begin{tabular}{|c|c|c|c|c|c|c|c|c|c|c|c|c|c|}
\hline \multirow{2}{*}{ Kinases } & \multicolumn{13}{|c|}{ Polyandrocarpamines (PAC) } \\
\hline & 1 & 2 & 3 & 4 & 5 & 6 & 7 & 8 & 9 & 10 & 11 & 12 & 13 \\
\hline CDK1/cyclin B & $>10$ & $>10$ & $>10$ & $>10$ & $>10$ & $>10$ & $>10$ & $>10$ & $>10$ & $>10$ & $>10$ & $>10$ & $>10$ \\
\hline CDK2/cyclin A & $>10$ & $>10$ & $\geq 10$ & $\geq 10$ & $>10$ & $>10$ & $>10$ & $>10$ & $>10$ & $>10$ & $>10$ & $>10$ & $>10$ \\
\hline $\mathrm{CDK} 5 / \mathrm{p} 25$ & $>10$ & $>10$ & $>10$ & $>10$ & $>10$ & $>10$ & $>10$ & $>10$ & $>10$ & $>10$ & $>10$ & $>10$ & $>10$ \\
\hline CDK9/cyclin T & 1.1 & 2 & $>10$ & $>10$ & $\geq 10$ & $>10$ & $>10$ & 0.51 & $>10$ & $>10$ & $>10$ & 0.9 & 1.8 \\
\hline $\mathrm{CK} 1 \delta / \varepsilon$ & 5.2 & $>10$ & $\geq 10$ & $\geq 10$ & $>10$ & $>10$ & $>10$ & $>10$ & 3.6 & $>10$ & $>10$ & 5 & $>10$ \\
\hline CLK1 & 0.43 & 1 & 2.2 & $\geq 10$ & 2.2 & $>10$ & $>10$ & $>10$ & $\geq 10$ & $>10$ & 4.2 & 0.47 & 0.59 \\
\hline CLK2 & 1.2 & 2.5 & 6.3 & $>10$ & 7.5 & $>10$ & $>10$ & $>10$ & $>10$ & $>10$ & $\geq 10$ & 0.64 & 2.42 \\
\hline CLK3 & 2.3 & 9.2 & $>10$ & $>10$ & $>10$ & $>10$ & $>10$ & $>10$ & $>10$ & $>10$ & $>10$ & 2.7 & 10 \\
\hline CLK4 & 0.4 & 0.95 & 2.3 & $\geq 10$ & 2.4 & $>10$ & $>10$ & $>10$ & $>10$ & $>10$ & 3.2 & 0.47 & 0.91 \\
\hline DYRK1A & 0.23 & 0.75 & 2.1 & 4 & 1.3 & $>10$ & $>10$ & $>10$ & $>10$ & 3 & 2.1 & 0.3 & 0.59 \\
\hline DYRK1B & 0.4 & 1.1 & 8.2 & $>10$ & 6.1 & $>10$ & $>10$ & $>10$ & $>10$ & $>10$ & 6.2 & 0.47 & 0.96 \\
\hline DYRK2 & 0.14 & 0.48 & 2.2 & 4.5 & 0.64 & $>10$ & $>10$ & $>10$ & $>10$ & 3.4 & 1.3 & 0.24 & 0.38 \\
\hline DYRK3 & 0.28 & 0.9 & $>10$ & 5.1 & 5.7 & $>10$ & $>10$ & $>10$ & $>10$ & $>10$ & 2.4 & 0.34 & 0.68 \\
\hline GSK $-3 \alpha / \beta$ & $>10$ & $>10$ & $>10$ & $>10$ & $>10$ & $>10$ & $>10$ & $>10$ & $>10$ & $>10$ & 2 & $>10$ & $>10$ \\
\hline PfGSK-3 & $>10$ & $>10$ & $>10$ & $>10$ & $>10$ & $>10$ & $>10$ & $>10$ & $>10$ & $>10$ & $>10$ & $>10$ & $>10$ \\
\hline LmCK1 & $>10$ & $>10$ & $>10$ & $>10$ & $>10$ & $>10$ & $>10$ & $>10$ & 0.63 & $>10$ & $>10$ & $>10$ & $>10$ \\
\hline
\end{tabular}

\section{Discussion}

Calcareous sponges of the Leucetta and Clathrina genera and a few other marine invertebrates produce a wealth of related yet diverse 2-aminoimidazolone alkaloids (Supplementary Table S2 and Supplementary Figure S5). The existence of these alkaloids in several Calcareous sponges raises several questions regarding their production. What is/are the biosynthetic pathway/s involved (see reference 19 for first hypothesis)? Are these molecules actually produced by the sponges or by associated microorganisms? In addition, these molecules may derive from a plankton source taken up (and possibly metabolized) by these filter-feeders. The fact that polyandrocarpamines were identified in ascidians (Polyandrocarpa sp.) [15] and that most 2-aminoimidazolones were discovered in calcareous sponges of the Leucetta and Clathrina genera (Supplementary Table S2) supports the hypothesis of microorganism-derived metabolites. However, cellular localization of clathridimine revealed its presence in sponge cells rather than in associated bacteria [22]. Several 2-aminoimidazolones 
were found in Notodoris nudibranchs and in the calcareous sponges they crawl and feed on [39-41]. Altogether these scattered results suggest possible transfers of 2-aminoimidazolones, their precursors and/or metabolites from one organism to another.

Many questions remain open regarding the physiological/ecological functions of these natural products. Are they used as repellant for predators or to control the expansion of associated microorganisms? Do they have specific functions for the sponge/ascidian/nudibranch metabolism itself? What are their natural molecular and cellular targets? Are they synthesized as kinase inhibitors or do they target other enzymes or structural proteins? Some of these may have orthologues in humans. The biological source, functions and natural targets of marine 2-aminoimidazolone alkaloids should be further investigated.

Only a few of these 2-aminoimidazolones have been chemically synthesized (Supplementary Table S2, right column) and are thus relatively easy to access for biological studies of their pharmacological properties. Nevertheless, they have already proved to be promising scaffolds for the design of potential therapeutic drug candidates. The identification of leucettamine B [6] and polyandrocarpamines $\mathrm{A}$ and $\mathrm{B}$ [this article] as potent and relatively selective inhibitors of disease-relevant kinases opens the way to the development of drug candidates for various applications [7,42]. This could be guided by the crystal structures of leucettines in complex with various kinases which have been solved [7]. At ManRos Therapeutics we are currently developing leucettines as DYRK1A inhibitory drug candidates $[6,7,42,43]$ to address cognitive deficits associated with DS [Nguyen et al., in preparation] and AD [44,45], but applications in cancer, inflammation and diabetes treatment should be investigated, too.

Besides kinase inhibition, polyandrocarpamine derivatives have been recently identified as inhibitors of cystathionine $\beta$-synthase, another potential therapeutic target for DS [46]. 2-Aminoimidazolones have been tested for evaluation of their antibacterial activity, anti-biofilm, antifungal, anticancer [32,47], anti-tuberculosis, anti-protozoan, antiviral, anti-inflammatory, adrenergic, anti-histaminic, anti-cholinergic, anti-serotoninergic, cardiac, immunosuppressive, leukotriene $\mathrm{B}_{4}$ receptor antagonistic $[8,48]$ and $\mathrm{AD}$ drug activities [12]. It would be of great interest to run more marine derived 2-aminoimidazolone alkaloids on wider enzyme/cell screening panels to identify novel targets and potentially novel therapeutic applications. Hopefully these molecules will add to the growing list of marine drugs and drug candidates developed in recent years $[49,50]$.

\section{Experimental Section}

\subsection{DNA Sequencing, Alignment and Phylogenetic Analyses}

The methods used for molecular phylogenetic analyses of Leucetta and Clathrina species are detailed in the Supplementary Data.

\subsection{Chemistry: Purification or Synthesis of Polyandrocarpamines A and B, and Analogues}

For the purification of clathridine and clathridimine, specimens of Clathrina clathrus were collected by scuba diving in the northwestern Mediterranean Sea (Marseille, France) between 10 and $15 \mathrm{~m}$ depth. Lyophilized samples $(4.2 \mathrm{~g})$ were extracted with 1:1 $\mathrm{CH}_{2} \mathrm{Cl}_{2} / \mathrm{MeOH}(3 \times 20 \mathrm{~mL}$, sonication for $15 \mathrm{~min})$ at room temperature. The 1:1 $\mathrm{CH}_{2} \mathrm{Cl}_{2} / \mathrm{MeOH}$ extract was concentrated under reduced pressure to yield a dark brown viscous oil $(208.1 \mathrm{mg})$, which was chromatographed on a $\mathrm{C}_{18}$ SPE column in a vacuum chamber $\left(\mathrm{H}_{2} \mathrm{O}, \mathrm{H}_{2} \mathrm{O} / \mathrm{MeOH} 1: 3, \mathrm{MeOH}, \mathrm{CH}_{2} \mathrm{Cl}_{2}, 100 \mathrm{~mL}\right.$ of each). The fraction eluted with $\mathrm{H}_{2} \mathrm{O} / \mathrm{MeOH}$, 1:3 (47.9 mg) was subjected to semi-preparative reversed-phase HPLC (Gemini $\mathrm{C}_{6}$-phenyl $10 \times 250 \mathrm{~mm}$ ) with increasing amounts of $\mathrm{CH}_{3} \mathrm{CN} / 0.1 \%$ formic acid in $\mathrm{H}_{2} \mathrm{O} / 0.1 \%$ formic acid as eluent (flow rate: $5 \mathrm{~mL} / \mathrm{min}$, wavelength: 254 and $280 \mathrm{~nm}$ ) and afforded clathridimine $(4.6 \mathrm{mg}$, $0.11 \%$ of sponge dry weight) and clathridine ( $2.8 \mathrm{mg}, 0.07 \%$ of sponge dry weight).

PAC1 to 11 were supplied by Rohan A. Davis The synthesis, purification and spectroscopic characterization of this focused polyandrocarpamine library has been described elsewhere [38]. 
Aplysinopsine and leucettamine B were synthesized according to a previously described protocol [51,52] respectively. Dispacamide was synthesized as described in [53].

The synthesis of polyandrocarpamines A \& B (PAC1 and PAC2) was performed from corresponding benzaldehyde derivatives, n-propylamine and 2-aminoimidazolin-4-one, the preparation of which was previously described in literature [53] (Figure 5). Guanidine (2.95 mmol, 1 eq) and HClaq $6 \mathrm{~N}(9 \mathrm{~mL})$ were heated at $120^{\circ} \mathrm{C}$ for $22 \mathrm{~h}$. Water was removed under vacuum and the crude product was solubilized in hot ethanol $(9 \mathrm{~mL})$. Diethylether $(6 \mathrm{~mL})$ was added, then the mixture was cooled to $0{ }^{\circ} \mathrm{C}$. After $6 \mathrm{~h}$, filtration was performed and the 2-aminoimidazolin-4-one was isolated as a white powder with a $49 \%$ yield. $R M N{ }^{1} \mathrm{H}\left(\mathrm{D}_{2} \mathrm{O}\right): \delta 4.18(\mathrm{~s}, 2 \mathrm{H}, \mathrm{H}-1) ; \mathrm{RMN}{ }^{13} \mathrm{C}\left(\mathrm{D}_{2} \mathrm{O}\right): \delta 48.5$ $(\mathrm{C}-1) ; 174.9(\mathrm{C}=\mathrm{O}) ;[\mathrm{M}-\mathrm{HCl}]^{+}=99.0427\left(99.0433 \mathrm{C}_{3} \mathrm{H}_{5} \mathrm{~N}_{3} \mathrm{O}\right) ; \mathrm{F}=200-202{ }^{\circ} \mathrm{C}$. PAC1 and PAC2 were then produced by mixing the corresponding benzaldehyde (vanillin or catechaldehyde $1.48 \mathrm{mmol}$, 1 eq) with $n$-propylamine ( $2.95 \mathrm{mmol}, 2 \mathrm{eq})$. The imine formation was performed under microwave irradiation at $60{ }^{\circ} \mathrm{C}$ for $30 \mathrm{~min}$ (maximized authorized power $60 \mathrm{~W}$ ). Acetonitrile was added to the crude imine with 2-aminoimidazolin-4-one (1.48 mmol, $1 \mathrm{eq})$, and the mixture was stirred at reflux for $63 \mathrm{~h}$. The solvent was removed under reduced pressure.

PAC1 was isolated as a beige powder with a $71 \%$ yield. $\mathrm{RMN}{ }^{1} \mathrm{H}\left(\mathrm{DMSO}-d_{6}\right): \delta 3.79\left(\mathrm{~s}, 3 \mathrm{H}, \mathrm{OCH}_{3}\right)$; $6.23(\mathrm{~s}, 1 \mathrm{H}, \mathrm{C}=\mathrm{CH}) ; 6.76(\mathrm{~d}, 1 \mathrm{H}, J=8.0 \mathrm{~Hz}, \mathrm{H}-5) ; 7.10\left(\mathrm{sl}, 2 \mathrm{H}, \mathrm{NH}_{2}\right) ; 7.35$ (sl, 1H, H-6); 7.56 (sl, 1H, H-2); $9.24(\mathrm{sl}, 1 \mathrm{H}, \mathrm{OH}) ; 10.38$ (sl, $1 \mathrm{H}, \mathrm{NH}) ; \mathrm{RMN}^{13} \mathrm{C}\left(\mathrm{DMSO}-d_{6}\right): \delta 56.2(\mathrm{OCH} 3) ; 114.6(\mathrm{C}-2) ; 116.0$ (C-5); $124.0(\mathrm{C}=\mathrm{CH}) ; 127.6(\mathrm{C}-6) ; 147.1(\mathrm{C}-3) ; 147.9(\mathrm{C}-4) ;[\mathrm{M}]^{+}=233.0797\left(233.0800 \mathrm{C}_{11} \mathrm{H}_{11} \mathrm{~N}_{3} \mathrm{O} 3\right) ; \mathrm{F}>260{ }^{\circ} \mathrm{C}$.

PAC2 was isolated as a beige powder with a $80 \%$ yield. $\mathrm{RMN}^{1} \mathrm{H}\left(\mathrm{DMSO}-d_{6}\right): \delta 6.14(\mathrm{~s}, 1 \mathrm{H}, \mathrm{C}=\mathrm{CH})$; $6.70(\mathrm{~d}, 1 \mathrm{H}, J=8.1 \mathrm{~Hz}, \mathrm{H}-5) ; 6.92\left(\mathrm{~s}, 2 \mathrm{H}, \mathrm{NH}_{2}\right) ; 7.27(\mathrm{~d}, 1 \mathrm{H}, J=7.5 \mathrm{~Hz}, \mathrm{H}-6) ; 7.53(\mathrm{~s}, 1 \mathrm{H}, \mathrm{H}-2) ; 8.81(\mathrm{~s}$, $1 \mathrm{H}, \mathrm{NH}) ; 9.19$ (s, $1 \mathrm{H}, \mathrm{OH}) ; 10.45(\mathrm{~s}, 1 \mathrm{H}, \mathrm{OH}) ; \mathrm{RMN}^{13} \mathrm{C}\left(\mathrm{DMSO}_{6}\right)$ ) $\delta 112.5(\mathrm{C}=\mathrm{CH}) ; 116.6(\mathrm{C}-5) ; 118.2$ (C-2); 123.1 (C-6); 128.2 (C-1); 146.0 (C-3); 146.6 (C-4); F > $260{ }^{\circ} \mathrm{C}$.

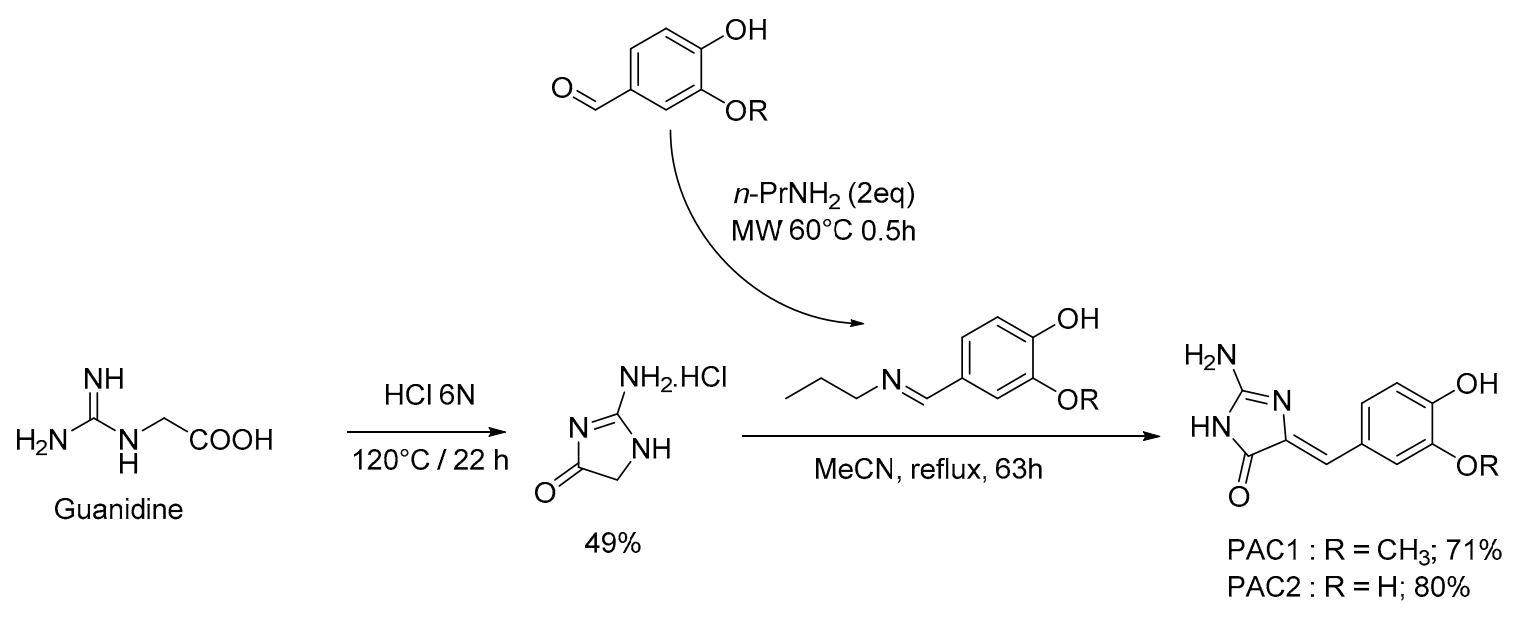

Figure 5. Scheme of the synthesis of polyandrocarpamines.

\subsection{Biology}

\subsubsection{Buffers}

Homogenization buffer: 25 mM MOPS; 15 mM EGTA; $15 \mathrm{mM} \mathrm{MgCl}_{2} ; 60 \mathrm{mM} \beta$-glycerophosphate; $15 \mathrm{mM}$ p-nitrophenylphosphate; $2 \mathrm{mM}$ dithiothreitol (DTT); $1 \mathrm{mM} \mathrm{Na}$ VO4; $1 \mathrm{mM} \mathrm{NaF} ; 1 \mathrm{mM}$ di-sodium phenylphosphate; $1 \mathrm{X}$ protease inhibitor cocktail; $0.2 \%$ Nonidet $\mathrm{P}-40$ substitute.

Buffer A: 10 mM MgCl $2 ; 1$ mM EGTA (MW 380.4); 1 mM DTT (MW 154.2); 25 mM Tris/HCl (MW 121.1), and; $50 \mu \mathrm{g} / \mathrm{mL}$ heparin.

Buffer C: $60 \mathrm{mM} \beta$-glycerophosphate; $30 \mathrm{mM}$-nitrophenylphosphate; $25 \mathrm{mM}$ MOPS pH 7.0; $5 \mathrm{mM}$ EGTA; $15 \mathrm{mM} \mathrm{MgCl} 2 ; 1 \mathrm{mM}$ DTT, and; $0.1 \mathrm{mM}$ sodium vanadate. 
All chemicals were purchased from Sigma Aldrich (St. Quentin Fallavier, France), unless otherwise stated and the protease inhibitor cocktail was from Roche (Boulogne-Billancourt, France).

\subsubsection{Production and Purification of the Parasitic Kinases}

The parasitic kinase genes (Supplementary Data, Table S3) were optimized for expression in E. coli, synthesized, and cloned in pGEX-6P-1 (GE Healthcare, Sigma-Aldrich, St. Quentin Fallavier, France) with the type II restriction enzymes BamHI and XhoI for glutathione S-transferase (GST) fusion at the $\mathrm{N}$-terminus (GenScript). Plasmids were transformed into chemically competent $E$. coli BL21(DE3), which were grown overnight at $37^{\circ} \mathrm{C}$ in $2 \times$ YT medium containing $100 \mu \mathrm{g} / \mathrm{mL}$ ampicillin. These cultures were used to inoculate $1 \mathrm{~L}$ volumes of $2 \times$ YT medium (containing $100 \mu \mathrm{g} / \mathrm{mL}$ ampicillin) in $5 \mathrm{~L}$ flasks. The cultures were allowed to grow at $37^{\circ} \mathrm{C}$ before the temperature was decreased to $18^{\circ} \mathrm{C}$. At an optical density at $600 \mathrm{~nm}$ (OD600) of about 1.0, protein expression was induced overnight at $18{ }^{\circ} \mathrm{C}$ with $0.1 \mathrm{mM}$ isopropyl $\beta$-D-1-thiogalactopyranoside (IPTG). The bacteria were harvested by centrifugation and were frozen at $-20^{\circ} \mathrm{C}$.

Cells were resuspended in a lysis buffer (PBS pH 7.4, 1\% NP40, 1 mM DTT, 1 mM EDTA, 1 mM PMSF) in the presence of protease inhibitor cocktail (Roche), and lysozyme was added to $1 \mathrm{mg} / \mathrm{mL}$ and incubated $1 \mathrm{~h}$ at $4{ }^{\circ} \mathrm{C}$ with gentle agitation. Cells were then sonicated on ice before $6 \mathrm{mM} \mathrm{MgCl}$ and $25 \mathrm{U} / \mathrm{mL}$ benzonase (Novagen, Merck Millipore, Fontenay sous Bois, France) were added to degrade nucleic acids and decrease sample viscosity. After centrifugation at $4{ }^{\circ} \mathrm{C}$, the soluble fraction was collected and proteins were bound to Glutathione sepharose $4 \mathrm{~B}$ beads (GE Healthcare). Beads were washed three times with lysis buffer and once with modified buffer C ( $25 \mathrm{mM}$ MOPS pH 7.0, $60 \mathrm{mM} \beta$-glycerophosphate, $15 \mathrm{mM}$-nitrophenylphosphate, $15 \mathrm{mM} \mathrm{EGTA}, 15 \mathrm{mM} \mathrm{MgCl} 2,2 \mathrm{mM}$ DTT, $1 \mathrm{mM}$ sodium vanadate). Proteins were eluted with elution buffer (buffer $\mathrm{C}$ containing $30 \mathrm{mM}$ reduced glutathione, $15 \%$ glycerol, and $\mathrm{pH}$ adjusted to 8.5$)$.

\subsubsection{Protein Kinase Assays}

Kinase activities were assayed in buffer $\mathrm{A}$ or $\mathrm{C}$ at $30^{\circ} \mathrm{C}$ at a final ATP concentration of $15 \mu \mathrm{mol} / \mathrm{L}$. Blank values were subtracted and activities were expressed in percent of the maximal activity, i.e., in the absence of inhibitors. Controls were performed with appropriate dilutions of DMSO.

The GS-1, CKS, CDK7/9 tide and RS peptide substrates were obtained from Proteogenix (Oberhausbergen, France).

CDK1/cyclin B (M phase starfish oocytes, native), CDK2/cyclin A and CDK5/p25 (human, recombinant) were prepared as previously described $[6,7]$. Their kinase activity was assayed in buffer A, with $1 \mathrm{mg}$ histone $\mathrm{H} 1 / \mathrm{mL}$, in the presence of $15 \mu \mathrm{mol} / \mathrm{L}\left[\gamma^{-3} \mathrm{P}\right]$ ATP $(3000 \mathrm{Ci} / \mathrm{mmol} ; 10 \mathrm{mCi} / \mathrm{mL})$ in a final volume of $30 \mu \mathrm{L}$. After $30 \mathrm{~min}$ incubation at $30^{\circ} \mathrm{C}$, the reaction was stopped by harvesting onto P81 phosphocellulose supernatant (Whatman, Dutscher SAS, Brumath, France) using a FilterMate harvester (PerkinElmer, Courtaboeuf, France) and were washed in 1\% phosphoric acid. Scintillation fluid was added and the radioactivity measured in a Packard counter.

CDK9/cyclin T (human, recombinant, expressed in insect cells) was assayed as described for CDK1/cyclin B, but using CDK7/9 tide (YSPTSPSYSPTSPSYSPTSPSKKKK) (8.1 $\mu \mathrm{g} /$ assay) as a substrate.

GSK-3 $\alpha / \beta$ (porcine brain, native) and PfGSK3 (plasmodium falciparum, recombinant, expressed in E. coli as GST fusion proteins) was assayed, as described for CDK1 with $0.5 \mathrm{mg}$ BSA $/ \mathrm{mL}+1 \mathrm{mM}$ DTT, using GS-1 (YRRAAVPPSPSLSRHSSPHQSpEDEEE) (pS stands for phosphorylated serine), a GSK-3 specific substrate [54].

CK1 $\delta / \varepsilon$ (porcine brain, native) and LmCK1 (leishmania major, recombinant, expressed in E. coli as HIS fusion proteins [34]) was assayed as described for CDK1 but in buffer C and using $25 \mu \mathrm{M}$ CKS peptide (RRKHAAIGpSAYSITA), a CK1-specific substrate [55].

DYRK1A, 1B, 2 and 3 (Human, recombinant, expressed in E. coli as GST fusion proteins) were purified by affinity chromatography on glutathione-agarose and assayed as described for CDK1/cyclin 
B with with $0.5 \mathrm{mg} \mathrm{BSA} / \mathrm{mL}+1 \mathrm{mM}$ DTT and using Woodtide (KKISGRLSPIMTEQ) (1.5 $\mu \mathrm{g} /$ assay) as a substrate, a residue of transcription factor FKHR.

CLK1, 2, 3 and 4 (mouse, recombinant, expressed in E. coli as GST fusion proteins) were assayed as described for CDK1/cyclin B with $0.5 \mathrm{mg}$ BSA $/ \mathrm{mL}+1 \mathrm{mM}$ DTT and RS peptide (GRSRSRSRSRSR).

Protozoan DYRKs and CLKs (recombinant, expressed in E. coli) were assayed as described for CDK1/cyclin B with $0.5 \mathrm{mg} \mathrm{BSA} / \mathrm{mL}+1 \mathrm{mM}$ DTT and Woodtide or RS peptide for DYRKs or CLKs isoforms.

\subsubsection{Kinase Interaction Panel (Ambit Biosciences/DiscoveRx)}

Assays were performed essentially as described previously [35]. For most assays, kinase-tagged T7 phage strains were grown in parallel in 24-well blocks in an E. coli host derived from the BL21 strain. E. coli were grown to log-phase and infected with T7 phage from a frozen stock (multiplicity of infection $\sim 0.1)$ and incubated with shaking at $32{ }^{\circ} \mathrm{C}$ until lysis $(\sim 90 \mathrm{~min})$. The lysates were centrifuged $(6000 \times g)$ and filtered $(0.2 \mu \mathrm{m})$ to remove cell debris. The remaining kinases were produced in HEK-293 cells and subsequently tagged with DNA for qPCR detection. Streptavidin-coated magnetic beads were treated with biotinylated small molecule ligands for $30 \mathrm{~min}$ at room temperature (RT) to generate affinity resins for kinase assays. The liganded beads were blocked with excess biotin and washed with blocking buffer (SeaBlock (Pierce, ThermoFisher Scientific, Illkirch, France), 1\% BSA, 0.05\% Tween 20, $1 \mathrm{mM}$ DTT) to remove unbound ligand and to reduce non-specific phage binding. Binding reactions were assembled by combining kinases, liganded affinity beads, and test compounds in $1 \times$ binding buffer (20\% SeaBlock, $0.17 \times$ PBS, 0.05\% Tween 20, 6 mM DTT). An 11-point threefold serial dilution of each test compound was prepared in $100 \%$ DMSO at $100 \times$ final test concentration which and subsequently diluted to $1 \times$ in the assay. All reactions were performed in polystyrene 96 -well plates in a final volume of $0.135 \mathrm{~mL}$. The assay plates were incubated at RT with shaking for $1 \mathrm{~h}$ and the affinity beads were washed four times with wash buffer $(1 \times$ PBS, $0.05 \%$ Tween 20$)$. The beads were then resuspended in elution buffer ( $1 \times$ PBS, $0.05 \%$ Tween $20,0.5 \mu \mathrm{M}$ non-biotinylated affinity ligand) and incubated at RT with shaking for $30 \mathrm{~min}$. The kinase concentration in the eluates was measured by qPCR.

\subsubsection{Thr286-Cyclin D1 Phosphorylation in SH-SY5Y Cells}

Cell treatments. SH-SY5Y cells conditionally expressing human DYRK1A [36], under the control of doxycycline (gift from Dr. Walter Becker) were cultured Dulbecco's Modified Eagle Medium (DMEM): Nutrient Mixture F-12 (DMEM/F-12, Gibco, c/o Invitrogen, Saint Aubin, France) containing 1\% Penicillin Streptomycin mixture (Gibco) and 10\% fetal bovine serum (FBS, Gibco) in a humidified, 5\% $\mathrm{CO}_{2}$ incubator at $37^{\circ} \mathrm{C}$. Cells were split routinely once a week. They were first rinsed with phosphate buffered saline (PBS, Gibco) and detached from the plate bottom using $2 \mathrm{~mL}$ Trypsin (Gibco) at $37^{\circ} \mathrm{C}$ for 3-4 min. Eight $\mathrm{mL}$ of fresh medium were added to the cell suspension and the mix was centrifuged for $3 \mathrm{~min}$ at $1000 \mathrm{rpm}$. The cell pellet was resuspended in fresh medium before seeding ( $\frac{1}{2}$ dilution) in new $150 \mathrm{~mm}$ plates. First, $1 \mu \mathrm{g} / \mathrm{mL}$ doxycycline was used to induce DYRK1A expression and cells were incubated $24 \mathrm{~h}$ in a humidified, $5 \% \mathrm{CO}_{2}$ incubator at $37^{\circ} \mathrm{C}$. Drugs $(0,3$ or $30 \mu \mathrm{M}$ final) were then added with a final concentration of $0.1 \%$ DMSO and cells were incubated for an additional $24 \mathrm{~h}$ in a humidified, $5 \% \mathrm{CO}_{2}$ incubator at $37^{\circ} \mathrm{C}$. Afterwards, cells were scrapped in medium and centrifuged for $5 \mathrm{~min}$ at $3000 \mathrm{rpm}$ at $4{ }^{\circ} \mathrm{C}$. The pellets were washed twice with PBS, centrifuge for $5 \mathrm{~min}$ at 10,000 $\mathrm{g}$ at $4{ }^{\circ} \mathrm{C}$, snap-frozen in liquid nitrogen and kept at $-80^{\circ} \mathrm{C}$.

Western blot analysis. Cell pellets were lysed in homogenization buffer. Protein extracts were mixed $(1: 1 v / v)$ with sample buffer $(2 \times$ NuPAGE LDS sample buffer, $200 \mathrm{mM}$ DTT) and $20 \mu \mathrm{g}$ of total proteins were loaded on NuPAGE 4-12\% Bis-Tris protein gels. Electrophoresis was run at $70 \mathrm{~V}$ in MOPS buffer for $4 \mathrm{~h}$. Rapid blot transfers were performed at 2.5 A/25 V for $7 \mathrm{~min}$. Blotting membranes were blocked in milk (5\% Regilait in Tris Buffered Saline with $0.1 \%$ Tween (TBST)) for $1 \mathrm{~h}$. Blotting membranes were incubated overnight at $4{ }^{\circ} \mathrm{C}$ with anti-cyclin D1 antibody (1:2000 dilution; Cell Signaling, Leiden, The Netherlands) or anti-phospho T286-cyclin D1 antibody (1:2000 dilution; Cell 
Signaling) or for $1 \mathrm{~h}$ at RT with anti-DYRK1A antibody (1:2000 dilution; Abnova, Taoyuan City, Taiwan) or anti-GAPDH antibody (1:30,000 dilution; Bio-Rad, Marnes-la-Coquette, France). Next, blotting membranes were incubated for $1 \mathrm{~h}$ at RT with goat anti-rabbit or goat anti-mouse antibodies (Bio-Rad). Chemiluminescent detection was achieved with homemade ECL-Tris buffer (100 mM Tris pH 8.5, $0.009 \% \mathrm{H}_{2} \mathrm{O}_{2}, 0.225 \mathrm{mM} p$-coumaric acid, $1.25 \mathrm{mM}$ luminol) with Fusion $\mathrm{F} \times 7$ camera software.

Supplementary Materials: This material is available free of charge via the internet at www.mdpi.com/1660-3397/ 15/10/316/s1.

Acknowledgments: We are grateful to Walter Becker for providing the DYRK1A-expressing SH-SY5Y cell line. This research was supported by grants from the "Fonds Unique Interministériel" (FUI) PHARMASEA and TRIAD projects (Laurent Meijer, Jean-Pierre Bazureau, François Carreaux), “Fondation Jérôme Lejeune" (Laurent Meijer), ANR grant TRANSLEISH and an EEC FP7-KBBE-2012 grant (BlueGenics) (Laurent Meijer). Morgane Cam is recipient of a CIFRE/ManRos Therapeutics Ph.D. fellowship. M.K. is funded by a fellowship from the Brazilian National Research Council (CNPq) and research grants from the CNPq and Coordination for the Improvement of Higher Education Personnel (CAPES). Rohan A. Davis acknowledges the National Health and Medical Research Council (NHMRC) for financial support (Grant APP1024314) and thanks the Australian Research Council (ARC) for support toward NMR and MS equipment (Grants LE0668477 and LE0237908), as well as financial support (Grant LP120200339).

Author Contributions: Laurent Meijer, Benoit Villiers, Tania Tahtouh conceived and designed the experiments; Nadège Loaëc, Emilie Durieu and Tania Tahtouh ran the in vitro kinase assays; Benoît Villiers cloned and expressed the unicellular kinases; Morgane Cam ran the SH-SY5Y experiments; Rohan A. Davis supplied the synthesized polyandrocarpamine derivatives PAC1 to PAC11; Mélanie Roue, Marie-Lise Bourguet-Kondracki and Peter Proksch provided clathridine, clathridimine and hymenialdisine, spongiacidin, respectively; Emmanuelle Limanton, Solène Guiheneuf, François Carreaux and Jean-Pierre Bazureau synthesized and provided leucettamine B, polyandrocarpamine A/B, aplysinopsine and dispacamide A; Aline Alencar and Michelle Klautau analyzed the phylogeny of Leucetta and Clathrina sp. and provided a full description of the genera; Eletta Attanasio and Marie-Lise Bourguet-Kondracki reviewed the 2-aminoimidazolone alkaloids; Laurent Meijer wrote the paper.

Conflicts of Interest: François Carreaux, Jean-Pierre Bazureau and Laurent Meijer are co-inventors on the leucettine patent. Laurent Meijer is CEO and CSO of ManRos Therapeutics which develops leucettines as DS and AD drug candidates.

\section{Abbreviations}

AD, Alzheimer's disease; CDKs, cyclin-dependent kinases; CK1, casein kinase 1; CK2, casein kinase 2; CLKs, cdc2-like kinases; DMEM, Dulbecco's Modified Eagle Medium; DMSO, dimethylsulfoxide; DS, Down syndrome; DTT, dithiothreitol; DYRKs, dual-specificity, tyrosine phosphorylation regulated kinases; GAPDH, glyceraldehydes-3-phosphate dehydrogenase; GSH, glutathione; GSK-3, glycogen synthase kinase-3; GST, glutathione-S-transferase; IC50, concentration inducing 50\% inhibition of the maximal kinase activity; IPTG, isopropyl $\beta$-D-1-thiogalactopyranoside; PBS, phosphate-buffered saline; RT, room temperature.

\section{References}

1. Roskoski, R., Jr. A historical overview of protein kinases and their targeted small molecule inhibitors. Pharmacol. Res. 2015, 100, 1-23. [CrossRef] [PubMed]

2. Fischer, E.H.; Krebs, E.G. Conversion of phosphorylase $b$ to phosphorylase $a$ in muscle extracts. J. Biol. Chem. 1955, 216, 121-132. [PubMed]

3. Wu, P.; Nielsen, T.E.; Clausen, M.H. Small-molecule kinase inhibitors: An analysis of FDA-approved drugs. Drug Discov. Today 2016, 21, 5-10. [CrossRef] [PubMed]

4. Wu, P.; Nielsen, T.E.; Clausen, M.H. FDA-approved small-molecule kinase inhibitors. Trends Pharmacol. Sci. 2015, 36, 422-439. [CrossRef] [PubMed]

5. Debdab, M.; Renault, S.; Eid, S.; Lozach, O.; Meijer, L.; Carreaux, F.; Bazureau, J.-P. An efficient method for the preparation of new analogs of leucettamine B under solvent-free microwave irradiation. Heterocycles 2009, 78, 1191-1203.

6. Debdab, M.; Carreaux, F.; Renault, S.; Soundararajan, M.; Fedorov, O.; Filippakopoulos, P.; Lozach, O.; Babault, L.; Tahtouh, T.; Baratte, B.; et al. Leucettines, a class of potent inhibitors of cdc2-like kinases and dual specificity, tyrosine phosphorylation regulated kinases derived from the marine sponge leucettamine B: Modulation of alternative pre-RNA splicing. J. Med. Chem. 2011, 54, 4172-4186. [CrossRef] [PubMed] 
7. Tahtouh, T.; Elkins, J.M.; Filippakopoulos, P.; Soundararajan, M.; Burgy, G.; Durieu, E.; Cochet, C.; Schmid, R.S.; Lo, D.C.; Delhommel, F.; et al. Selectivity, cocrystal structures, and neuroprotective properties of leucettines, a family of protein kinase inhibitors derived from the marine sponge alkaloid leucettamine B. J. Med. Chem. 2012, 55, 9312-9330. [CrossRef] [PubMed]

8. Chan, G.W.; Mong, S.; Hemling, M.E.; Freyer, A.J.; Offen, P.M.; De Brosse, C.W.; Sarau, H.M.; Westley, J.W. New leukotriene B4 receptor antagonist: Leucettamine A and related imidazole alkaloids from the marine sponge Leucetta microraphis. J. Nat. Prod. 1993, 56, 116-121. [CrossRef] [PubMed]

9. Sullivan, J.D.; Giles, R.L.; Looper, R.E. 2-Aminoimidazoles from Leucetta Sponges: Synthesis and biology of an important pharmacophore. Curr. Bioact. Compd. 2009, 5, 39-78. [CrossRef]

10. Koswatta, P.B.; Lovely, C.J. Structure and synthesis of 2-aminoimidazole alkaloids from Leucetta and Clathrina sponges. Nat. Prod. Rep. 2011, 28, 511-528. [CrossRef] [PubMed]

11. Roué, M.; Quévrain, E.; Domart-Coulon, I.; Bourguet-Kondracki, M.L. Assessing calcareous sponges and their associated bacteria for the discovery of new bioactive natural products. Nat. Prod. Rep. 2012, 29, 739-751. [CrossRef] [PubMed]

12. Žula, A.; Kikelj, D.; Ilaš, J. 2-Aminoimidazoles in medicinal chemistry. Mini Rev. Med. Chem. 2013, 13, 1921-1943. [CrossRef] [PubMed]

13. Yin, Z.; Zhu, M.; Davidson, E.H.; Bottjer, D.J.; Zhao, F.; Tafforeau, P. Sponge grade body fossil with cellular resolution dating 60 Myr before the Cambrian. Proc. Natl. Acad. Sci. USA 2015, 112, E1453-E1460. [CrossRef] [PubMed]

14. Rossi, A.L.; Campos, A.P.C.; Barroso, M.M.S.; Klautau, M.; Archanjo, B.S.; Borojevic, R.; Farina, M.; Werckmann, J. Long-range crystalline order in spicules from the calcareous sponge Paraleucilla magna (Porifera, Calcarea). Acta Biomater. 2014, 10, 3875-3884. [CrossRef] [PubMed]

15. Davis, R.A.; Aalbersberg, W.; Meo, S.; Moreira da Rocha, R.; Ireland, C.M. The isolation and synthesis of polyandrocarpamines A and B. Two new 2-aminoimidazolone compounds from the Fijian ascidian, Polyandrocarpa sp. Tetrahedron Lett. 2002, 58, 3263-3269. [CrossRef]

16. Davis, R.A.; Baron, P.S.; Neve, J.E.; Cullinane, C. A microwave-assisted stereoselective synthesis of polyandrocarpamines A and B. Tetrahedron Lett. 2008, 50, 880-882. [CrossRef]

17. Lindel, T.; Hoffmann, H. Synthesis of dispacamide from the marine sponge Agelas dispar. Tetrahedron Lett. 1997, 38, 8935-8938. [CrossRef]

18. Fresneda, P.M.; Molina, P.; Sanz, M.A. A convergent approach to midpacamide and dispacamide pyrrole-imidazole marine alkaloids. Tetrahedron Lett. 2001, 42, 851-854. [CrossRef]

19. Travert, N.; Al-Mourabit, A. A likely biogenetic gateway linking 2-aminoimidazolinone metabolites of sponges to proline: Spontaneous oxidative conversion of the pyrrole-proline-guanidine pseudo-peptide to dispacamide A. J. Am. Chem. Soc. 2004, 126, 10252-10253; Erratum in 2005, 127, 10454. [CrossRef] [PubMed]

20. Hollenbeak, K.H.; Schmitz, F.J. Aplysinopsin: Antineoplastic tryptophan derivative from the marine sponge Verongia spengelii. Lloydia 1977, 40, 479-481. [PubMed]

21. Bialonska, D.; Zjawiony, J.K. Aplysinopsins-Marine indole alkaloids: Chemistry, bioactivity and ecological significance. Mar. Drugs 2009, 7, 166-183. [CrossRef] [PubMed]

22. Roué, M.; Domart-Coulon, I.; Ereskovsky, A.; Djediat, C.; Perez, T.; Bourguet-Kondracki, M.L. Cellular localization of clathridimine, an antimicrobial 2-aminoimidazole alkaloid produced by the Mediterranean calcareous sponge Clathrina clathrus. J. Nat. Prod. 2010, 73, 1277-1282. [CrossRef] [PubMed]

23. Cimino, G.; de Rosa, S.; de Stefano, S.; Mazzarella, L.; Puliti, R.; Sodano, G. Isolation \& X-ray crystal structure of a novel bromo-compound from two marine sponges. Tetrahedron Lett. 1982, 23, 767-768.

24. Sharma, G.M.; Buyer, J.; Pomerantz, M.W. Characterization of a yellow compound isolated from the marine sponge Phakellia flabellata. J. Chem. Soc. Chem. Commun. 1980, 10, 435-436. [CrossRef]

25. Williams, D.H.; Faulkner, J. Isomers and tautomers of hymenialdisine and debromohymenialdisine. Nat. Prod. Lett. 1996, 9, 57-64. [CrossRef]

26. Xu, Y.Y.; Yakushijin, K.; Horne, D.A. Synthesis of C(11)N(5) Marine sponge alkaloids: (+/-)-hymenin, stevensine, hymenialdisine, and debromohymenialdisine. J. Org. Chem. 1997, 62, 456-464. [CrossRef]

27. Papeo, G.; Posteri, H.; Borghi, D.; Varasi, M. A new glycociamidine ring precursor: Syntheses of (Z)-hymenialdisine, (Z)-2-debromohymenialdisine, and (+/-)-endo-2-debromohymenialdisine. Org. Lett. 2005, 7, 5641-5644. [CrossRef] [PubMed] 
28. Nguyen, T.N.; Tepe, J.J. Preparation of hymenialdisine, analogues and their evaluation as kinase inhibitors. Curr. Med. Chem. 2009, 16, 3122-3143. [CrossRef] [PubMed]

29. Meijer, L.; Thunnissen, A.M.W.H.; White, A.; Garnier, M.; Nikolic, M.; Tsai, L.H.; Walter, J.; Cleverley, K.E.; Salinas, P.C.; Wu, Y.Z.; et al. Inhibition of cyclin-dependent kinases, GSK-3 $\beta$ and casein kinase 1 by hymenialdisine, a marine sponge constituent. Chem. Biol. 2000, 7, 51-63. [CrossRef]

30. Wan, Y.; Hur, W.; Cho, C.Y.; Liu, Y.; Adrian, F.J.; Lozach, O.; Bach, S.; Mayer, T.; Fabbro, D.; Meijer, L.; et al. Synthesis and target identification of hymenialdisine analogs. Chem. Biol. 2004, 11, 247-259. [CrossRef] [PubMed]

31. Nguyen, T.D.; Nguyen, X.C.; Longeon, A.; Keryhuel, A.; Le, M.H.; Kim, Y.H.; Chau, V.M.; Bourguet-Kondracki, M.L. Antioxidant benzylidene 2-aminoimidazolones from the Mediterranean sponge Phorbas topsenti. Tetrahedron 2012, 68, 9256-9259. [CrossRef]

32. Ling, Y.; Wang, Z.Q.; Xiao, Y.A.; Zhu, C.; Shen, L.; Wang, X.M.; Hui, Y.; Wang, X.Y. Benzylidene 2-aminoimidazolones derivatives: Synthesis and in vitro evaluation of anti-tumor carcinoma activity. Chem. Pharm. Bull. (Tokyo) 2013, 61, 1081-1084. [CrossRef] [PubMed]

33. Droucheau, E.; Primot, A.; Thomas, V.; Mattei, D.; Knockaert, M.; Richardson, C.; Sallicandro, P.; Alano, P.; Jafarshad, A.; Baratte, B.; et al. Plasmodium falciparum glycogen synthase kinase-3: Molecular model, expression, intracellular localisation and selective inhibitors. Biochim. Biophys. Acta 2004, 1697, 181-196. [CrossRef] [PubMed]

34. Rachidi, N.; Taly, J.F.; Durieu, E.; Leclercq, O.; Aulner, N.; Prina, E.; Pescher, P.; Notredame, C.; Meijer, L.; Späth, G.F. Pharmacological assessment defines the Leishmania donovani casein kinase 1 as a drug target and reveals important functions in parasite viability and intracellular infection. Antimicrob. Agents Chemother. 2014, 58, 1501-1515. [CrossRef] [PubMed]

35. Karaman, M.W.; Herrgard, S.; Treiber, D.K.; Gallant, P.; Atteridge, C.E.; Campbell, B.T.; Chan, K.W.; Ciceri, P.; Davis, M.I.; Edeen, P.T.; et al. A quantitative analysis of kinase inhibitor selectivity. Nat. Biotechnol. 2008, 26, 127-132. [CrossRef] [PubMed]

36. Soppa, U.; Schumacher, J.; Florencio Ortiz, V.; Pasqualon, T.; Tejedor, F.J.; Becker, W. The Down syndrome-related protein kinase DYRK1A phosphorylates p27(Kip1) and cyclin D1 and induces cell cycle exit and neuronal differentiation. Cell Cycle 2014, 13, 2084-2100. [CrossRef] [PubMed]

37. Najas, S.; Arranz, J.; Lochhead, P.A.; Ashford, A.L.; Oxley, D.; Delabar, J.M.; Cook, S.J.; Barallobre, M.J.; Arbonés, M.L. DYRK1A-mediated cyclin D1 degradation in neural stem cells contributes to the neurogenic cortical defects in Down syndrome. EBioMedicine 2015, 2, 120-134. [CrossRef] [PubMed]

38. Baron, P.S.; Neve, J.E.; Camp, D.; Suraweera, L.; Lam, A.; Lai, J.; Jovanovic, L.; Nelson, C.; Davis, R.A. Design, synthesis and spectroscopic characterisation of a focused library based on the polyandrocarpamine natural product scaffold. Magn. Reson. Chem. 2013, 51, 358-363. [CrossRef] [PubMed]

39. Carmely, S.; Ilan, M.; Kashman, Y. 2-Aminoimidazole alkaloids from the marine sponge Leucetta chagosensis. Tetrahedron 1989, 45, 2193-2200. [CrossRef]

40. Alvi, K.A.; Crews, P.; Loughhead, D.G. Structures and total synthesis of 2-aminoimidazoles from a Notodoris nudibranch. J. Nat. Prod. 1991, 54, 1509-1515. [CrossRef]

41. Alvi, K.A.; Peters, B.M.; Hunter, L.M.; Crews, P. 2-Aminoimidazoles and their zinc complexes from indo-pacific Leucetta sponges and Notodoris nudibranchs. Tetrahedron 1993, 49, 329-336. [CrossRef]

42. Nguyen, T.L.; Fruit, C.; Hérault, Y.; Meijer, L.; Besson, T. Dual-specificity tyrosine phosphorylation-regulated kinase 1A (DYRK1A) inhibitors: A survey of recent patent literature. Expert Opin. Ther. Pat. 2017, in press.

43. Tahtouh, T.; Durieu, E.; Villiers, B.; Bruyere, C.; Nguyen, T.L.; Fant, X.; Ahn, K.H.; Khurana, L.; L'helgoual'ch, J.M.; Limanton, E.; et al. Structure/activity relationship in the leucettine family of kinase inhibitors. J. Med. Chem. 2017, submitted.

44. Fant, X.; Durieu, E.; Chicanne, G.; Payrastre, B.; Sbrissa, D.; Shisheva, A.; Limanton, E.; Carreaux, F.; Bazureau, J.P.; Meijer, L. Cdc-like/dual-specificity tyrosine phosphorylation-regulated kinases Leucettine L41 induces mTOR-dependent autophagy: Implication for Alzheimer's disease. Mol. Pharmacol. 2014, 85, 441-450. [CrossRef] [PubMed]

45. Naert, G.; Ferré, V.; Meunier, J.; Keller, E.; Malmström, S.; Givalois, L.; Carreaux, F.; Bazureau, J.P.; Maurice, T. Leucettine L41, a DYRK1A-preferential DYRKs/CLKs inhibitor, prevents memory impairments and neurotoxicity induced by oligomeric A $\beta 25-35$ peptide administration in mice. Eur. Neuropsychopharmacol. 2015, 25, 2170-2182. [CrossRef] [PubMed] 
46. Thorson, M.K.; Van Wagoner, R.M.; Harper, M.K.; Ireland, C.M.; Majtan, T.; Kraus, J.P.; Barrios, A.M. Marine natural products as inhibitors of cystathionine beta-synthase activity. Bioorg. Med. Chem. Lett. 2015, 25, 1064-1066. [CrossRef] [PubMed]

47. Zhang, N.; Zhang, Z.; Wong, I.L.; Wan, S.; Chow, L.M.; Jiang, T. 4,5-Di-substituted benzyl-imidazol-2-substituted amines as the structure template for the design and synthesis of reversal agents against P-gp-mediated multidrug resistance breast cancer cells. Eur. J. Med. Chem. 2014, 83, 74-83. [CrossRef] [PubMed]

48. Boehm, J.C.; Gleason, J.G.; Pendrak, I.; Sarau, H.M.; Schmidt, D.B.; Foley, J.J.; Kingsbury, W.D. Synthesis and LTB4 receptor antagonist activities of the naturally occurring LTB4 receptor antagonist Leucettamine A and related analogues. J. Med. Chem. 1993, 36, 3333-3340. [CrossRef] [PubMed]

49. Newman, D.J.; Cragg, G.M. Current status of marine-derived compounds as warheads in anti-tumor drug candidates. Mar. Drugs 2017, 15, 99. [CrossRef] [PubMed]

50. Newman, D.J.; Cragg, G.M. Drugs and drug candidates from marine sources: An assessment of the current "state of play". Planta Med. 2016, 82, 775-789. [CrossRef] [PubMed]

51. Djura, P.; Faulkner, D.J. Metabolites of the marine sponge Dercitus sp. J. Org. Chem. 1980, 45, $735-737$. [CrossRef]

52. Roué, N.; Bergman, J. Synthesis of the marine alkaloid Leucettamine B. Tetrahedron 1999, 55, 14729-14738. [CrossRef]

53. Guihéneuf, S.; Paquin, L.; Carreaux, F.; Durieu, E.; Meijer, L.; Bazureau, J.P. An efficient approach to dispacamide A and its derivatives. Org. Biomol. Chem. 2012, 10, 978-987. [CrossRef] [PubMed]

54. Primot, A.; Baratte, B.; Gompel, M.; Borgne, A.; Liabeuf, S.; Romette, J.L.; Costantini, F.; Meijer, L. Purification of GSK-3 by affinity chromatography on immobilised axin. Protein Expr. Purif. 2000, 20, 394-404. [CrossRef] [PubMed]

55. Reinhardt, J.; Ferandin, Y.; Meijer, L. Purification CK1 by affinity chromatography on immobilised axin. Protein Expr. Purif. 2007, 54, 101-109. [CrossRef] [PubMed]

(C) 2017 by the authors. Licensee MDPI, Basel, Switzerland. This article is an open access article distributed under the terms and conditions of the Creative Commons Attribution (CC BY) license (http:/ / creativecommons.org/licenses/by/4.0/). 